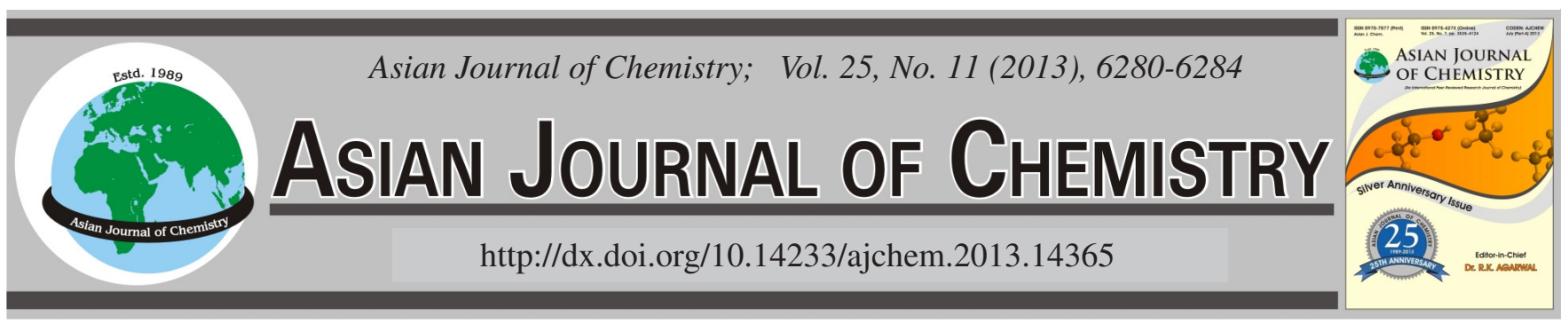

\title{
Effect of Microwave-Assisted Enzymatic Aqueous Extraction on the Quality Attributes of Maize (Zea mays L.) Seed Oil
}

\author{
Farooq Anwar $^{1,2,{ }^{*}, \text { Ammara Yaqoub }^{2}, \text { Shaukat Ali }_{\text {Shahid }}^{3} \text { and Maleeha Manzoor }}{ }^{2}$
}

\author{
${ }^{1}$ Department of Chemistry, University of Sargodha, Sargodha-40100, Pakistan \\ ${ }^{2}$ Department of Chemistry and Biochemistry, University of Agriculture, Faisalabad-38040, Pakistan \\ ${ }^{3}$ Department of Physics, University of Agriculture, Faisalabad-38040, Pakistan \\ *Corresponding author: Fax: +92 48 3222121; Tel: +92 48 9230546; E-mail: fqanwar@yahoo.com
}

\begin{abstract}
The present work evaluates and compares the quality characteristics of microwave-assisted enzymatic aqueous extracted maize (Zea mays L.) seed oil with those of hexane-extracted oil and control oil. The oil content from microwave-assisted enzymatic aqueous extracted maize seeds was found to be 2.52-3.60 \% compared with 2.22-3.32\% in control seeds, revealing an increment of 10-11\% in the oil extraction yield due to microwave enzymatic treatment. The physicochemical parameters such as density, refractive index, free fatty acid, iodine value, colour, saponification number and unsaponifiable matter and fatty acids composition of the microwave-assisted enzymatic aqueous extracted maize oil were quite comparable with those of hexane-extracted oil and control oil, showing no significant $(p>0.05)$ differences among the extraction methods. The oxidative stability of the microwave-assisted enzymatic aqueous extracted oil was found to be considerably improved in comparison to the control oil and hexane-extracted oil as evident by the determinations of conjugated dienes, conjugated trienes, peroxide and $p$-anisidine values. It was concluded that microwave-enzymatic adjuvant improved the oil extraction yield as well as the oxidation properties of the oil produced without altering its other quality attributes.
\end{abstract}

Key Words: Maize seed oil, Microwaves, Enzymatic pretreatment, Aqueous extraction, Fatty acids composition.

\section{INTRODUCTION}

Extraction of vegetable oils from oilseed crops is a key step to determine their applications for edible and /or industrial uses. Soxhlet extraction, involving the use of $n$-hexane or petroleum ether as extraction solvent, has been explored as an efficient technique to recovering the oils from oil seeds and other oil-bearing materials. However, the use of such flammable solvent is associated with some serious concerns related to emission of toxic volatile compounds, process safety hazards and environmental problems ${ }^{1,2}$. Besides, involvement of high operational temperature during the conventional hexane extraction process not only affects the food quality of oil but can also reduce the nutritional value of the meals to be used as an animal feed ${ }^{3}$.

Taking into consideration of the growing regulatory concerns and consumer preferences, researchers are looking forward to replace conventional hexane extraction process with some safer and eco-friendly alternative extraction techniques. In this regard, several oil extraction techniques including those of cold pressing and aqueous extraction have been explored over the years ${ }^{2,4,5}$. While most of such organic solvent free oil extraction techniques offer lower oil yields which can be interestingly increased by enzymatic pretreatment of seeds, prior to oil extraction ${ }^{6-11}$.

Recently, enzyme-assisted aqueous extraction has emerged as an efficient and environment friendly safer alternative technique for extraction of better quality vegetable oil and meals from seeds ${ }^{1,6,12-14}$. The main function of using the enzymes such as cellulase, $\alpha$-amylase and pectinase during oil extraction process is to effectively hydrolyze the structural polysaccharides which form oil seed cell walls or the proteins which make the cell and lipid body membranes ${ }^{2,7,15-17}$.

Microwave heating can be used to support and facilitate the extraction of natural products from plant materials. Microwave-assisted extraction technique are becoming important as alternative to other extraction methods like Soxhlet, sonication and supercritical fluid extractions ${ }^{18,19}$ due to its typical advantages like reduced extraction time, energy saving, better process control and efficiency ${ }^{20-22}$. Microwave-assisted enzymatic aqueous extraction utilizes the combined capability of microwave energy and aqueous enzymatic treatment leading to increasing the recovery of oil extraction yields from seeds by effective and efficient hydrolysis of the seed cell wall ${ }^{11}$. 
Maize (Zea mays L.), belonging to Gramineae family, is a traditional oil seed crop containing relatively lower amount $(2.5-5.5 \%)$ of oil among others. Nutritionally, maize seed oil is important as it can play positive role in lowering the serum cholesterol due to presence of essential polyunsaturated fatty acids with potential health functions ${ }^{23,24}$. The presence of high amount of antioxidants like tocopherols in maize seed oil imparts it good oxidative stability ${ }^{24}$. Maize seed oil mainly contains linoleic acid (61.9\%), oleic acid (24\%), palmitic acid $(11 \%)$, stearic acid $(2 \%)$ and linolenic acid $(0.7 \%)^{25}$.

As far as we know, no earlier literature reports are available on the microwave-assisted enzymatic aqueous extraction of oil from maize (Zea mays) seeds. So, the present research work was aimed to evaluate the effects of microwave-assisted enzymatic aqueous extraction on the yield and physicochemical characteristics of maize seed oil. The quality attributes of microwave assisted enzymatic aqueous extracted oils were studied and compared with those of hexane extracted oil and control oil.

\section{EXPERIMENTAL}

Maize (Zea mays L.) seeds of two varieties (C-20 and DTC Hybrid) were obtained from the Ayub Agricultural Research Institute (AARI), Faisalabad, Pakistan. These two maize varieties were cultivated under the same environmental conditions. All the reagents/chemicals (analytical) used in present research work were procured from Merck (Darmstadt, Germany) and/ or Sigma-Aldrich (Buchs, Switzerland). Pure standards of fatty acid methyl esters (FAMEs) were purchased from Sigma Chemical Co. (St. Louis, MO). Viscozyme L (multienzyme complex, comprising mainly carbohydrases such as cellulase, arabanase, $\beta$-glucanase, hemicellulase and xylanase) was obtained from Novozymes Bagsvaerd (Denmark).

Extraction of oil: The sun-dried maize seeds (100 g) were crushed in an electric grinder, and placed in a paper thimble and fed to a Soxhlet extractor connected with a water condenser and a $500 \mathrm{~mL}$ round-bottomed flask. The extraction was continued for $6 \mathrm{~h}$ with $n$-hexane (b.p $65-68{ }^{\circ} \mathrm{C}$ ) on a water bath. After completing the extraction, the excess of the solvent ( $n$-hexane) was recovered by distilling off under reduced pressure using a rotary vacuum evaporator (EYELA, N.N. Series, Rikakikai Co. Ltd., Tokyo, Japan). The oil recovered was kept in brown coloured sample vial at $4{ }^{\circ} \mathrm{C}$ until used for further experiments.

Microwave-assisted enzymatic aqueous extraction: The maize oil seeds, placed in a glass Petri plate (Pyrex), were subjected to microwave heating (medium power setting) for 1 min using a domestic microwave oven (Dawlance, DW180, Korea). After microwave treatment, maize seeds were allowed to cool down at ambient temperature prior to oil extraction. The micro waved ground maize seeds were mixed with distilled water in a ratio of 1:6 (w/v) in a conical flask. The resulting mixture was boiled for $5 \mathrm{~min}$ and allowed to cool down at room temperature, followed by adjustment of optimum $\mathrm{pH}$ with $0.5 \mathrm{~N} \mathrm{NaOH} / \mathrm{HCl}$, prior to the addition of enzyme (Viscozyme L) $2 \%$ seed weight basis. The incubation was done in a temperature controlled incubator (Galli, Model 2800 , Italy) at $45^{\circ} \mathrm{C}$ for $2 \mathrm{~h}$ with constant shaking at $120 \mathrm{rpm}$ followed by centrifugation $\left(8000 \mathrm{rpm}, 20^{\circ} \mathrm{C}\right.$ ) for 20 min using a centrifuge machine (Sigma, 3K 30, Osterode am Harz, Germany) to separate the oil, from creamy/aqueous phases ${ }^{8}$. The top oil phase was collected using a micro-pipette and then transferred into a beaker leaving the meal at the bottom of the flask. The wet meal was thoroughly mixed and then dried in a hot air-oven (VOC-300 SD; EYELA, Tokyo, Japan) at $65^{\circ} \mathrm{C}$ followed by grinding using a grinder mill. A control (without enzyme) experiment/trial was also executed under the same set of experimental conditions.

Analysis of oil seed residues: The meal (residue left after oil extraction) was analyzed for protein, fiber and ash contents. Protein, fibre and ash contents were determined according to AOAC official method ${ }^{26}$, ISO method ${ }^{27}$ and ISO method ${ }^{28}$, respectively.

Analysis of extracted oils: The physico-chemical properties such as density, refractive index, iodine value, peroxide value, acidity, saponification value and unsaponifiable matter of the extracted oils were analyzed according to AOCS methods ${ }^{29}$. Colour intensity was measured using Lovi bond Tintometer (Tintometer Ltd., Salisbury, Wiltshire, United Kingdom). Conjugated dienes and conjugated trienes were monitored as specific extinctions using the absorbance data at $232 \mathrm{~nm}$ and $270 \mathrm{~nm}$, respectively. The oils under testing were mixed with appropriate volume of iso-octane to get the absorbance within the acceptable limits (0.2-0.8). Absorbance of the resulting reaction mixture was recorded using a spectrophotometer (U-2001, Hitachi Instrument Inc. Tokyo, Japan) and specific extinctions $\left(\varepsilon_{1}{ }^{1 \%} \mathrm{~cm}(\lambda)\right)$ calculated according to IUPAC protocol $^{30}$. To determine the $p$-anisidine value, the oils were tested as per IUPAC protocol ${ }^{30}$. The oils under testing after dissolving in iso-octane, were reacted with $p$-anisidine reagent to get a coloured complex, the absorbance of which was recorded at $350 \mathrm{~nm}$ using a spectrophotometer (U-2001, Hitachi Instruments Inc. Tokyo, Japan).

Gas chromatographic fatty acid analysis: The tested oils samples were converted into fatty acid methyl esters (FAMEs) through base-catalyzed trans esterification according to the standard IUPAC method ${ }^{30}$. A SHIMADZU gas chromatograph model 17-A, connected with a flame ionization detector (FID) was used. Separation of the FAMEs was done on a methyl lignocerate coated (film thickness $0.20 \mu \mathrm{m}$ ) SP2330 (SUPLECO, Inc., Bellefonte, PA) polar capillary column (30 $\mathrm{m} \times 0.25 \mathrm{~mm}$ ). The initial column oven temperature was maintained at $180^{\circ} \mathrm{C}$ for $2 \mathrm{~min}$ and then linearly increased by the rate of $5^{\circ} \mathrm{C} / \mathrm{min}$ to final temperature of $220^{\circ} \mathrm{C}$ and then finally held for $10 \mathrm{~min}$. Injector temperature was set at $230^{\circ} \mathrm{C}$ while the flame ionization detector at $240{ }^{\circ} \mathrm{C}$. Oxygen-free extra pure nitrogen (purity $99.99 \%$ ) was flushed through the column as carrier gas (flow rate of $5 \mathrm{~mL} / \mathrm{min}$ ). The identification of the unknown FAMEs was based on matching their retention times with those of pure standards. The quantitative measurements were made using a chromatography station for Windows (CSW32) data handling software (Data APEX Ltd., Czech Republic). The fatty acid composition was expressed as a relative percentage of the total peak area.

Statistical analysis: All the experiments were performed in triplicate and the results thus generated were statistically 
TABLE-1

PROXIMATE ANALYSIS OF MAIZE SEEDS

\begin{tabular}{|c|c|c|c|c|c|c|}
\hline \multirow{2}{*}{ Parameter } & \multicolumn{2}{|c|}{ Solvent extraction } & \multicolumn{2}{|c|}{ MEAE } & \multicolumn{2}{|c|}{ Control } \\
\hline & $\mathrm{C}-20$ & DTC & $\mathrm{C}-20$ & DTC & $\mathrm{C}-20$ & DTC \\
\hline Oil content (\%) & $3.25 \pm 0.04^{\mathrm{a}}$ & $4.00 \pm 0.06^{\mathrm{a}}$ & $2.52 \pm 0.05^{\mathrm{b}}$ & $3.60 \pm 0.07^{b}$ & $2.22 \pm 0.04^{\mathrm{c}}$ & $3.32 \pm 0.08^{\mathrm{c}}$ \\
\hline Moisture (\%) & $10.60 \pm 0.20^{\mathrm{a}}$ & $10.90 \pm 0.32^{\mathrm{a}}$ & $10.50 \pm 0.46^{\mathrm{a}}$ & $10.80 \pm 0.28^{\mathrm{a}}$ & $10.50 \pm 0.46^{\mathrm{a}}$ & $10.80 \pm 0.38^{\mathrm{a}}$ \\
\hline Fiber $(\%)$ & $4.00 \pm 0.18^{\mathrm{a}}$ & $4.10 \pm 0.15^{\mathrm{a}}$ & $4.00 \pm 0.29^{a}$ & $3.99 \pm 0.21^{\mathrm{a}}$ & $4.00 \pm 0.41^{\mathrm{a}}$ & $4.01 \pm 0.24^{\mathrm{a}}$ \\
\hline Protein (\%) & $8.90 \pm 0.35^{\mathrm{a}}$ & $9.10 \pm 0.32^{\mathrm{a}}$ & $8.79 \pm 0.41^{\mathrm{a}}$ & $8.90 \pm 0.29^{a}$ & $8.69 \pm 0.39^{\mathrm{a}}$ & $8.89 \pm 0.43^{a}$ \\
\hline Ash (\%) & $1.59 \pm 0.08^{a}$ & $1.67 \pm 0.03^{\mathrm{a}}$ & $1.49 \pm 0.05^{\mathrm{a}}$ & $1.65 \pm 0.09^{\mathrm{a}}$ & $1.50 \pm 0.02^{\mathrm{a}}$ & $1.63 \pm 0.04^{\mathrm{a}}$ \\
\hline
\end{tabular}

Values are mean \pm SD for three different samples of each variety analyzed individually in triplicate; Different superscript letters within the same row indicate significant $(p<0.05)$ differences of means among the extraction methods; MEAE = Microwave-assisted enzymatic aqueous extraction

TABLE-2

PHYSICOCHEMICAL CHARACTERISTICS OF MAIZE SEED OILS

\begin{tabular}{|c|c|c|c|c|c|c|}
\hline \multirow{2}{*}{ Parameter } & \multicolumn{2}{|c|}{ Solvent extraction } & \multicolumn{2}{|c|}{ MEAE } & \multicolumn{2}{|c|}{ Control } \\
\hline & $\mathrm{C}-20$ & DTC & $\mathrm{C}-20$ & DTC & $\mathrm{C}-20$ & DTC \\
\hline Colour unit (Yellow Unit) & $12.71 \pm 0.46^{\mathrm{a}}$ & $8.10 \pm 0.31^{\mathrm{a}}$ & $10.76 \pm 0.36^{\mathrm{b}}$ & $5.92 \pm 0.40^{b}$ & $10.85 \pm 0.51^{\mathrm{b}}$ & $5.35 \pm 0.39^{b}$ \\
\hline Colour unit (Red Unit) & $1.95 \pm 0.19^{\mathrm{a}}$ & $1.82 \pm 0.11^{\mathrm{a}}$ & $1.52 \pm 0.03^{\mathrm{a}}$ & $1.92 \pm 0.06^{\mathrm{a}}$ & $1.45 \pm 0.07^{\mathrm{a}}$ & $1.83 \pm 0.07^{\mathrm{a}}$ \\
\hline Refractive index $\left(40^{\circ} \mathrm{C}\right)$ & $1.4655 \pm 0.002^{\mathrm{a}}$ & $1.4656 \pm 0.003^{\mathrm{a}}$ & $1.4654 \pm 0.002^{\mathrm{a}}$ & $1.4653 \pm 0.004^{\mathrm{a}}$ & $1.4653 \pm 0.003^{a}$ & $1.4654 \pm 0.005^{\mathrm{a}}$ \\
\hline Density $(\mathrm{mg} / \mathrm{mL})\left(24^{0} \mathrm{C}\right)$ & $0.98 \pm 0.04^{\mathrm{a}}$ & $0.95 \pm 0.05^{\mathrm{a}}$ & $0.97 \pm 0.06^{\mathrm{a}}$ & $0.98 \pm 0.09^{\mathrm{a}}$ & $0.98 \pm 0.04^{\mathrm{a}}$ & $0.95 \pm 0.02^{\mathrm{a}}$ \\
\hline Iodine value ( $\mathrm{g}$ of $\mathrm{I} / 100 \mathrm{~g}$ of oil) & $116.25 \pm 2.10^{\mathrm{a}}$ & $117.85 \pm 2.35^{\mathrm{a}}$ & $117.35 \pm 3.47^{\mathrm{a}}$ & $118.75 \pm 3.21^{\mathrm{a}}$ & $116.35 \pm 2.32^{\mathrm{a}}$ & $117.75 \pm 2.93^{\mathrm{a}}$ \\
\hline Unsaponifiable matter $(\%)$ & $0.69 \pm 0.02^{\mathrm{a}}$ & $0.56 \pm 0.01^{\mathrm{a}}$ & $0.58 \pm 0.03^{\mathrm{a}}$ & $0.49 \pm 0.03^{\mathrm{ab}}$ & $0.56 \pm 0.05^{b}$ & $0.45 \pm 0.04^{\mathrm{b}}$ \\
\hline $\begin{array}{l}\text { Saponification Value (mg of } \\
\mathrm{KOH} / \mathrm{g} \text { of oil) }\end{array}$ & $189.08 \pm 3.34^{\mathrm{a}}$ & $193.57 \pm 3.63^{\mathrm{a}}$ & $183.06 \pm 3.49^{\mathrm{a}}$ & $187.91 \pm 3.22^{a}$ & $185.03 \pm 4.31^{\mathrm{a}}$ & $186.03 \pm 3.21^{\mathrm{a}}$ \\
\hline Free Fatty Acid (\% as oleic acid) & $0.19 \pm 0.05^{\mathrm{a}}$ & $0.16 \pm 0.04^{\mathrm{a}}$ & $0.17 \pm 0.02^{\mathrm{a}}$ & $0.14 \pm 0.03^{\mathrm{a}}$ & $0.18 \pm 0.02^{\mathrm{a}}$ & $0.15 \pm 0.01^{\mathrm{a}}$ \\
\hline
\end{tabular}

Values are mean \pm SD for three different samples of each variety analyzed individually in triplicate; Different superscript letters within the same row indicate significant $(p<0.05)$ differences of means among the extraction methods; MEAE= Microwave-assisted enzymatic aqueous extraction

analyzed using statistical software STATISTICA 5.5 (Stat Soft Inc., Tulsa, Oklahoma, USA). Statistically significant difference was denoted at $p<0.05$. Data were reported as mean values \pm standard deviation derived from triplicate determinations.

\section{RESULTS AND DISCUSSION}

The percentage (wt \%) of oil recovered $(2.52,3.60 \%)$ from two varieties (C-20 and DTC) of maize seeds by microwave-assisted enzyme aqueous extraction, although considerably $(P<0.05)$ higher than that recovered $(2.22,3.32 \%)$ in control method (without enzyme), was however lower than that obtained by hexane extraction process (HEP) (3.25, $4.00 \%$ ), respectively (Table-1). The higher amount of oil extracted by microwave-assisted enzymatic aqueous extraction in comparison to control process might be attributed to the enzymatic treatment which effectively degraded the cell wall of seed to make more oil available for extraction ${ }^{12,31}$. Interestingly the recovery of the oil from the seeds can be improved using a mixture of enzymes ${ }^{32,33}$. Enzymatic treatment, during aqueous extraction, not only degrade the seed cell wall but it can also lead to effective solubilization and hydrolysis of proteins, which are probably involved in the network feature of the cotyledon cells and in the protein (oleosin) based membranes that surrounds the lipid bodies, thereby liberating more quantity of the oil into the extraction media ${ }^{12,31}$.

The analysis of the oil seed residues in Table- 1 of two maize varieties (C20 and DTC) revealed that the protein contents $(8.79-8.90 \%)$ in enzyme treated seeds were quite comparable with those of control (8.69-8.89\%) and hexaneextracted seeds(8.90-9.10\%). Besides, the analysis of the oil seed residues tested revealed no significant $(p>0.05)$ variation for crude fiber and ash contents among different extraction techniques employed. No earlier microwave-assisted enzymatic aqueous extraction reports are available on these parameters of maize seeds with which to compare the results of our present analysis.

Table-2 shows the data for some physicochemical parameters of the maize seed oils produced by different extraction methods. There were no significant $(p>0.05)$ differences in the iodine value (117.35-118.75 $\mathrm{g}$ of iodine/100 $\mathrm{g}$ of oil), density at $24{ }^{\circ} \mathrm{C}(0.97-0.98 \mathrm{~g} / \mathrm{mL})$, refractive Index at $40{ }^{\circ} \mathrm{C}$ (1.4653-1.4654), saponification (183.06-187.91 mg of KOH/ g), unsaponifiable matter $(0.49-0.58 \%)$ and the contents of free fatty acids ( $\%$ as oleic acid) $(0.14-0.17)$ of the maize seed oils obtained by either of the extraction techniques. The colour index $[(5.92-10.76 \mathrm{Y})+(1.52-1.92 \mathrm{Y})]$ of the microwavedassisted enzymatic aqueous extracted maize seed oils were found to be slightly varied than those of the control oil and hexane-extracted oil. Oils with minimum colour intensity are favoured for edible applications as well as for some oleochemical uses. Colour of the vegetable oils is the result of presence of some pigments such as chlorophyll that are extracted alongwith the oil from seeds ${ }^{34}$. Due to the lack of reports on the routine physico-chemical characteristics of microwave-assisted enzymatic aqueous extraction maize seed oil it was not possible to compare the results of present investigation with those of literature.

The results related to the determination of some oxidation parameters of two varieties (C-20 and DTC) of maize seed oil, produced by different extraction means, are given in Table3. The specific extinctions (representative of conjugated dienes and conjugated trienes, respectively) at 232 and $270 \mathrm{~nm}$ of the microwave-assisted enzymatic aqueous extraction maize seed oils, which express the oxidative deterioration of the oils $\mathrm{s}^{34}$, ranged from 1.90 to 2.15 and 0.60 to 0.69 , respectively. These values were quite comparable to those of the control oil (2.10 


\begin{tabular}{|c|c|c|c|c|c|c|c|}
\hline \multicolumn{8}{|c|}{$\begin{array}{c}\text { TABLE-3 } \\
\text { OXIDATIVE STATE OF MAIZE SEED OILS }\end{array}$} \\
\hline \multirow{2}{*}{ Parameter } & \multicolumn{2}{|c|}{ Solvent extraction } & \multicolumn{3}{|c|}{ MEAE } & \multicolumn{2}{|c|}{ Control } \\
\hline & C-20 & DTC & & $\mathrm{C}-20$ & DTC & $\mathrm{C}-20$ & DTC \\
\hline Conjugateddienes $\varepsilon_{1}{ }^{1 \%}{ }_{\mathrm{cm}(\lambda)}(\lambda=232)$ & $2.94 \pm 0.07^{\mathrm{a}}$ & $2.72 \pm 0.01^{\mathrm{a}}$ & & $15 \pm 0.09^{b}$ & $.90 \pm 0.05^{b}$ & $2.10 \pm 0.03^{b}$ & $2.19 \pm 0.02^{b}$ \\
\hline Conjugated trienes $\varepsilon_{1}{ }^{1 \%(}{ }_{\mathrm{cm}(\lambda)}(\lambda=268)$ & $0.87 \pm 0.02^{\mathrm{a}}$ & $0.90 \pm 0.03^{\mathrm{a}}$ & & $59 \pm 0.02^{\mathrm{b}}$ & $.60 \pm 0.03^{b}$ & $0.67 \pm 0.04^{\mathrm{b}}$ & $0.71 \pm 0.03^{\mathrm{b}}$ \\
\hline Peroxide value (meq/Kg of oil) & $3.10 \pm 0.08^{\mathrm{a}}$ & $2.89 \pm 0.05^{\mathrm{a}}$ & & $71 \pm 0.06^{\mathrm{b}}$ & $.29 \pm 0.04^{b}$ & $2.74 \pm 0.06^{\mathrm{b}}$ & $2.50 \pm 0.07^{\mathrm{b}}$ \\
\hline$p$-Anisidine value & $3.50 \pm .08^{\mathrm{a}}$ & $3.41 \pm 0.09^{\mathrm{a}}$ & & $10 \pm 0.07^{\mathrm{c}}$ & $.01 \pm 0.08^{\mathrm{b}}$ & $3.18 \pm 0.07^{b}$ & $3.16 \pm 0.06^{\mathrm{b}}$ \\
\hline \multicolumn{8}{|c|}{$\begin{array}{l}\text { Values are mean } \pm \text { SD for three different samples of each variety analyzed individually in triplicate; Different superscript letters within the same } \\
\text { row indicate significant }(p<0.05) \text { differences of means among the extraction methods; MEAE = Microwave-assisted enzymatic aqueous extraction }\end{array}$} \\
\hline \multicolumn{8}{|c|}{$\begin{array}{r}\text { TABLE-4 } \\
\text { FATTY ACID COMPOSITION (\%) }\end{array}$} \\
\hline \multirow[t]{2}{*}{ FA } & \multicolumn{3}{|c|}{ Solvent Extraction } & \multicolumn{2}{|c|}{ MEAE } & \multicolumn{2}{|c|}{ Control } \\
\hline & $\mathrm{C}-20$ & DTC & & $\mathrm{C}-20$ & DTC & $\mathrm{C}-20$ & DTC \\
\hline Palmitic acid (C16:0) & $10.00 \pm 0.43^{\mathrm{a}}$ & $12.91 \pm$ & & $9.80 \pm 0.30^{\mathrm{a}}$ & $12.00 \pm 0.20^{\mathrm{a}}$ & $10.00 \pm 0.30^{\mathrm{a}}$ & $12.86 \pm 0.15^{\mathrm{a}}$ \\
\hline Stearic acid (C18:0) & $3.20 \pm 0.06^{\mathrm{a}}$ & $2.70 \pm 0$ & & $3.15 \pm 0.09^{\mathrm{a}}$ & $2.65 \pm 0.19^{\mathrm{a}}$ & $3.20 \pm 0.07^{\mathrm{a}}$ & $2.75 \pm 0.20^{\mathrm{a}}$ \\
\hline Oleic acid (C18:1) & $36.70 \pm 0.61^{\mathrm{a}}$ & $36.20 \pm$ & & $37.00 \pm 0.66^{\mathrm{a}}$ & $37.55 \pm 0.90^{\mathrm{a}}$ & $36.40 \pm 0.51^{\mathrm{a}}$ & $37.30 \pm 0.70^{\mathrm{a}}$ \\
\hline Linoleic acid (C18:2) & $47.90 \pm 0.49^{a}$ & $46.00 \pm$ & & $48.50 \pm 1.00^{\mathrm{a}}$ & $45.60 \pm 0.74^{\mathrm{a}}$ & $47.99 \pm 0.75^{\mathrm{a}}$ & $44.99 \pm 0.40^{\mathrm{a}}$ \\
\hline Linolenic acid (C18:3) & $0.60 \pm 0.10$ & $0.57 \pm($ & & $0.62 \pm 0.10$ & $0.60 \pm 0.07$ & $0.58 \pm 0.10$ & $0.59 \pm 0.06$ \\
\hline Arachidic acid (C20:0) & $0.45 \pm 0.04$ & $0.39 \pm($ & & $0.41 \pm 0.04$ & $0.38 \pm 0.06$ & $0.40 \pm 0.10$ & $0.45 \pm 0.07$ \\
\hline
\end{tabular}

to 2.19 and 0.68 to 0.71 , respectively) but significantly ( $p<$ 0.05 ) lower than those of hexane extracted oil (2.72 to 2.94 and 0.87 to 0.90 , respectively). The peroxide value of the microwave-assisted enzymatic aqueous extraction maize oil, ranging from 2.29 to $2.71 \mathrm{meq} / \mathrm{kg}$, were comparable to that of the control oil ( 2.50 to $2.74 \mathrm{meq} / \mathrm{kg})$. However, the value was significantly $(p<0.05)$ lower than that of the hexane extracted oil ( 2.89 to $3.10 \mathrm{meq} / \mathrm{kg}$ ) indicating superior oxidative stability of the microwave-assisted enzymatic aqueous extraction oil which might be linked with the mild extraction conditions used in this process. The conventional extraction technique, used to recover vegetable oil by means of organic solvents through soxhelt apparatus, involves relatively higher operational temperature which might affect the oil quality unfavourably, especially the oxidation sate of oils leading to generation of rancid and bad odors and thus decrease in nutritive value. No previous reports were available on the oxidation parameters of microwave-assisted enzymatic aqueous extraction oil to compare the results of present findings.

Table- 4 shows the fatty acid composition of microwaveassisted enzymatic aqueous extracted oil in comparison to control oil and hexane extracted oil produced from the two varieties (C-20 and DTC) of maize seeds. Separation of fatty acids as GC chromatograms is depicted by Figs. 1-4. The contents of oleic acid (C18:1) and linoleic acid (C18:2) in the microwave-assisted enzymatic aqueous extraction oil ranged from 36.95 to $37.55 \%$ and 35.99 to $49.99 \%$, respectively, followed by palmitic acid (C16:0) and stearic acid (C18:0) with contribution at 9.80 to $19.11 \%$ and 3.25 to $7.55 \%$, respectively. No significant $(p<0.05)$ difference was recorded for the qualitative data and amounts of the oil fatty acids in relation to the extraction procedures employed. Fatty acids analysis of the vegetable oil is regarded as one of the most important quality-oriented tasks as most of the properties of oils/fats either linked with edible uses and/or oleo chemical applications are defined by the profile of fatty acids ${ }^{10,11}$.

\section{Conclusion}

It could be concluded from the results of the present research work that microwave assisted enzymatic aqueous

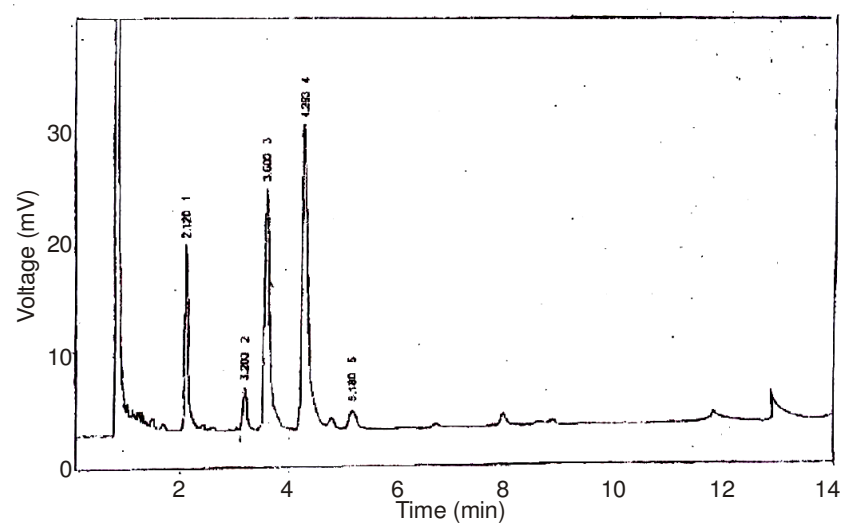

Fig. 1. Typical GC chromatogram showing the separation of fatty acids of microwave-assisted enzymatic aqueous extracted maize seed oil from DTC variety of maize

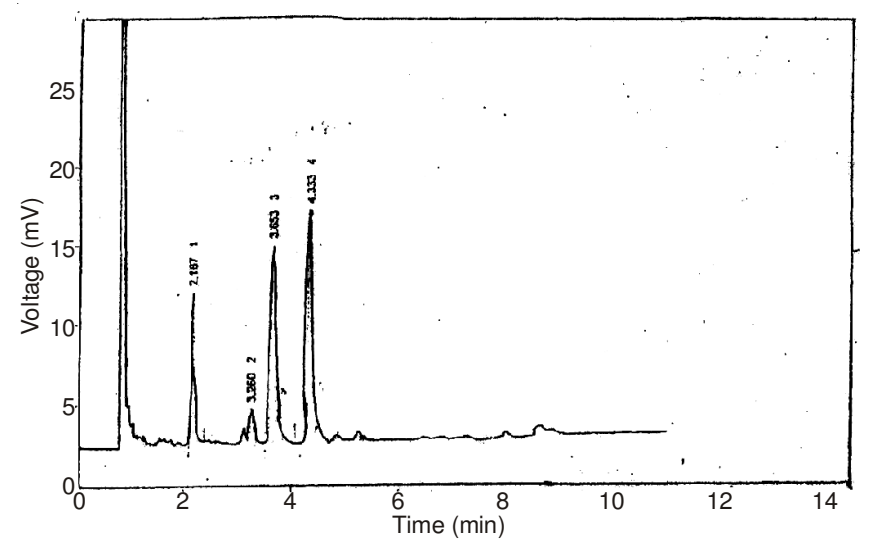

Fig. 2. Typical GC chromatogram showing the separation of fatty acids of microwave-assisted enzymatic aqueous extracted maize seed oil from C-20 variety of maize 


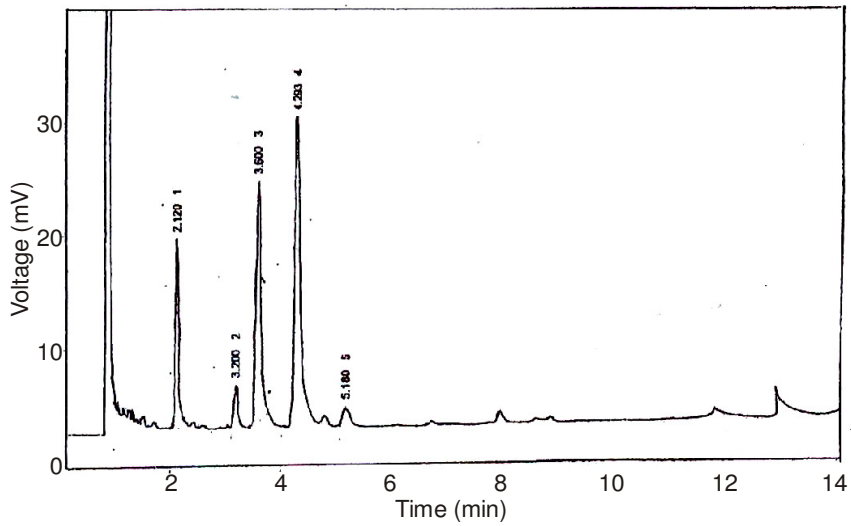

Fig. 3. Typical GC chromatogram showing the separation of fatty acids of hexane extracted oil (HEO) from hybrid DTC variety of maize

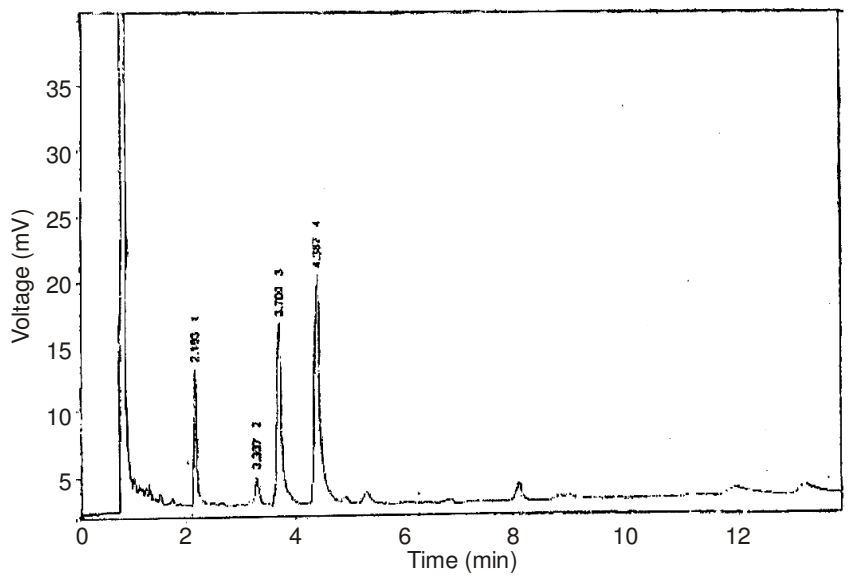

Fig. 4. Typical GC chromatogram showing the separation of fatty acids of HEO from C-20 variety of maize

process considerably enhanced the oil extraction yield from maize seeds compared to the control (without enzyme treatment) with out exerting negative impact on the quality attributes of the oils produced. On the other hand, the oil recovered by the enzymatic method exhibited improved oxidation sate without showing any appreciable change in the quality or contents of fatty acids. Further work to evaluate the effect of enzyme adjuvant on the concentration of oils valuable minor components such as tocopherols, phenolics, phytosterols during microwave-assisted enzymatic aqueous extraction is recommended.

\section{ACKNOWLEDGEMENTS}

The authors greatly acknowledged Higher Education Commission (HEC) of Pakistan for providing financial grant through project No.20-1344/R\&D/09/2290, titled "Exploration of Microwave-Enzyme-Assisted Methods for Extraction of Seed Oils" to accomplish this research work.

\section{REFERENCES}

1. P. Bhattacharjee, R.S. Singhal and S.R. Tiwari, J. Food Eng., 79, 892 (2007).

2. S. Latif and F. Anwar, Grasas Y Aceites, 59, 67 (2008).

3. C.G. Soto, R. Chamy and M. Zuniga, J. Chem. Eng. Japan, 37, 326 (2004).

4. K.C. Rhee, C.M. Carter and K.M. Mattil, J. Food. Sci., 37, 90 (1972).

5. L. Shi, J. Lu, G. Jones, P.A. Loretan and W.A. Hill, Life Support Biosci., 5, 225 (1998)

6. P. Hanmoungjai, D.L. Pyle and K. Niranjan, J. Am. Oil Chem. Soc., 78, 817 (2001)

7. S. Latif, F. Anwar and M. Ashraf, J. Food Lipid, 14, 424 (2007).

8. S. Latif, L. Diosady and F. Anwar, Eur. J. Lipid Sci. Tech., 110, 887 (2008).

9. S. Latif, F. Anwar, A.I. Hussain and S. Mahmood, Eur. J. Lipids Sci. Tech., 113, 1012 (2011).

10. S. Latif and F. Anwar, Food Chem., 125, 679 (2011)

11. H. Rui, L. Zhang, Z. Li and Y. Pan, J. Food. Engg., 93, 482 (2009).

12. S. Latif and F. Anwar, J. Am. Oil Chem. Soc., 86, 393 (2009).

13. A. Rosenthal, D.L. Pyle, K. Niranjan, S. Gilmour and L. Trinca, Enzyme Microb. Technol., 28, 499 (2001).

14. A. Sharma, S.K. Khare and M.N. Gupta, J. Am. Oil Chem. Soc., 79, 215 (2002).

15. K. Sosulsky, F.W. Sosulsky and E. Coxworth, J. Am. Oil Chem. Soc., 65, 357 (1988).

16. A. Rosenthal, D.L. Pyle and K. Niranjan, Enzyme Microb. Technol., 19, 402 (1996).

17. B.P. Lamsal, C. Reitmeier, P.A. Murphy and L.A. Johnson, J. Am. Oil Chem. Soc., 83, 732 (2006).

18. G. Flamini, M. Tebano, P.L. Cioni, L. Ceccarini, A.S. Ricci and I. Longo, J. Chromatogr. A, 1143, 36 (2007).

19. A. Longarese-Patron and M.P. Canizares-Macias, Talanta, 69, 882 (2006).

20. A. Loupy, A. Petit, J. Hamelin, F. Texier-Boullet, P. Jacquault and D. Mathe, Synthesis, 1213 (1998).

21. F. Priego-Capote and M.D. Luque de Castro, Talanta, 65, 81 (2005).

22. M.A. Ferhat, B.Y. Meklati, J. Smadja and F. Chemat, J. Chromatogr. A, 1112, 121 (2006).

23. B. Delplanque, Grass Lipids, 7, 467 (2000).

24. A. Menkisr, W. Liu, W.S. White, B. Maziya-Dixon and T. Rocheford, Food Chem., 109, 521 (2008).

25. N. Mehmood, Characterization and Quality Evaluation of Different Brands of Com oil. B.Sc. (Hons) Agri., Univ. Agri. Faisalabad (2004).

26. Association of Official Analytical Chemists (AOAC), Official Methods of Analysis of the Association of Official Analytical Chemists, $15^{\text {th }}$ edn. AOAC Inc., Virginia, Method 976.05 (1990).

27. International Organization for Standardization (ISO), Animal Feeding Stuffs Determination of Nitrogen and Calculation of Crude Protein Contents, ISO, Geneva, Standard No. 5983 (1981).

28. International Organization for Standardization (ISO), Oilseeds Residues Determination of Total ash, ISO, Geneva, Standard No. 749 (1977).

29. American Oil Chemist's Society (AOCS), Official and Recommended Practices of the American Oil Chemists Society, $5^{\text {th }}$ edn., AOCS Press, Champaign (1997).

30. International Union of Pure and Applied Chemistry (IUPAC), Standard Methods for the Analysis of Oils, Fats and Derivatives, $7^{\text {th }}$ Revised and Enlarged edn, edited by C. Paquot and A. Hautfenne, Blackwell Scientific, London (1987).

31. J.T.C. Tzen and A.H.C. Huang, J. Biol. Chem., 117, 327 (1992).

32. O.C. Mcglone, C. Lopez-Munguia and J.C. Carter, J. Food Sci., 51, 695 (1986).

33. K. Tano-Debrah and Y. Ohta, J. Am. Oil Chem. Soc., 72, 251 (1995).

34. F. Anwar, S. Latif and M. Ashraf, J. Am. Oil Chem. Soc., 83, 323 (2006). 